\title{
Diazotrophy under continuous light in a marine unicellular diazotrophic cyanobacterium, Gloeothece sp. 68DGA
}

\section{Correspondence \\ Kaori Ohki \\ kaoriohki@fpu.ac.jp}

Received 20 March 2008

Revised 16 April 2008

Accepted 22 April 2008

\author{
Yukiko Taniuchi, ${ }^{1}+$ Shinya Yoshikawa, ${ }^{1}$ Shin-ichi Maeda, ${ }^{2}$ Tatsuo Omata $^{2}$ \\ and Kaori Ohki ${ }^{1}$ \\ ${ }^{1}$ Department of Marine Bioscience, Fukui Prefectural University, 1-1 Gakuencho, Obama, Fukui \\ 917-0003, Japan \\ ${ }^{2}$ Laboratory of Molecular Plant Physiology, Graduate School of Bioagricultural Sciences, Nagoya \\ University, Furo-cho, Chikusa-ku, Nagoya, Aichi 464-9601, Japan
}

\begin{abstract}
Nitrogenase is extremely sensitive to molecular oxygen $\left(\mathrm{O}_{2}\right)$, and unicellular diazotrophic cyanobacteria separate nitrogen $\left(\mathrm{N}_{2}\right)$-fixation and photosynthesis to protect nitrogenase from $\mathrm{O}_{2}$ produced by photosynthesis. When grown under $12 \mathrm{~h}$ light/12 $\mathrm{h}$ dark cycles (LD), the marine unicellular diazotrophic cyanobacterium Gloeothece sp. 68DGA expressed the nitrogenase protein and its activity (acetylene reduction activity) only during the dark phase. However, this strain was able to grow diazotrophically under continuous light (CL). To determine whether nitrogenase synthesis and $\mathrm{N}_{2}$-fixation are temporally separated from photosynthesis in the Gloeothece cells that have fully acclimated to $\mathrm{CL}$, the proportion of cells containing nitrogenase (the Fe-protein of nitrogenase) in the culture was measured using an immunocytochemical technique. Cells were grown in a continuous-culture device to maintain constant cell density. Under LD, the cells showed diurnal oscillation of nitrogenase activity, photosynthesis, respiration and the expression and the abundance of the Fe-protein. The oscillation was gradually reduced after the transfer of the cells to CL, and was lost after 23-25 days of cultivation under CL. In CL-acclimated cultures, the Fe-protein was always detected in about $94 \%$ of the cells, although the nitrogenase activity was about one-third of the maximum activity in LD-acclimated cultures. These results suggest that synthesis of nitrogenase proceeds without diurnal oscillation in the CL-acclimated cells of Gloeothece sp. 68DGA. As the respiration rate in CL-acclimated culture was as high as the maximum rate observed in LD-acclimated culture, $\mathrm{O}_{2}$-uptake mechanism(s) may have been upregulated to maintain low intracellular $\mathrm{pO}_{2}$.
\end{abstract}

\section{INTRODUCTION}

Diazotrophic cyanobacteria are the only oxygenic phototrophs among the nitrogen $\left(\mathrm{N}_{2}\right)$-fixing organisms. As nitrogenase (EC 1.18.6.1), the enzyme complex (the Feprotein, and $\alpha$ - and $\beta$-subunits of the MoFe-protein) that catalyses $\mathrm{N}_{2}$-fixation, is extremely labile to molecular oxygen $\left(\mathrm{O}_{2}\right)$ (Postgate, 1998), cyanobacteria have developed many strategies to separate $\mathrm{N}_{2}$-fixation and photosynthesis spatially or temporally (Bergman et al., 1997; Fay, 1992; Gallon, 1992; Wolk, 1999). Most unicellular diazotrophic cyanobacteria fix $\mathrm{N}_{2}$ during the

†Present address: Department of Marine Biotechnology and Resources, National Sun Yat-sen University, Kaoshiung 80424, Taiwan, ROC.

Abbreviations: $\mathrm{CL}$, continuous light; $\mathrm{DAB}, 3,3^{\prime}$-diaminobenzidine tetrachloride; LD, 12 h light/12 h dark cycles; SHAM, salicylhydroxamic acid.

Two supplementary figures are available with the online version of this paper. dark phase of light/dark cycles or in the night under atmospheric conditions (Gallon \& Chaplin, 1988; Huang \& Chow, 1986; Mitsui et al., 1986; Reddy et al., 1993; Taniuchi \& Ohki, 2007). However, some diazotrophic unicellular cyanobacteria fix $\mathrm{N}_{2}$ during the light phase of $12 \mathrm{~h}$ light/12 h dark cycles (LD) even though photosynthetic $\mathrm{O}_{2}$-evolution occurs. For example, Gloeothece sp. PCC6909 fixed $\mathrm{N}_{2}$ preferentially during the light phase of LD when it was maintained in continuous culture (OrtegaCalvo \& Stal, 1991). We previously found that $\mathrm{N}_{2}$-fixation of Gloeothece sp. 68DGA, which normally is observed only in the dark phase under LD, proceeded after the dark-tolight transition when the assimilation of ammonia was inhibited by the addition of L-methionine sulfoximine (Taniuchi \& Ohki, 2007). Furthermore, many unicellular cyanobacteria are able to grow diazotrophically under continuous light (CL) (Colón-López et al., 1997; Grobbelaar et al., 1986; Ohki et al., 2008; Taniuchi \& 
Ohki, 2007). These observations suggest that the diurnal separation of $\mathrm{N}_{2}$-fixation and photosynthesis may not be essential for diazotrophic growth of unicellular cyanobacteria: the cells may fix $\mathrm{N}_{2}$ while evolving $\mathrm{O}_{2}$. If this is the case, studies on $\mathrm{N}_{2}$-fixation by unicellular cyanobacteria under CL will provide useful information for understanding the mechanism(s) for protection of nitrogenase from $\mathrm{O}_{2}$, although this light condition never exists in natural environments. However, it is also possible that the diurnal separation is maintained under CL by the circadian clock, as is typically observed after the transition from LD to CL, enabling effective $\mathrm{N}_{2}$-fixation in the absence of $\mathrm{O}_{2}$ evolution. Even if no synchronicity is observed in the whole culture after prolonged cultivation of the cells under CL, individual cells may separate $\mathrm{N}_{2}$-fixation and photosynthesis diurnally. We cannot distinguish between the two possibilities as long as the nitrogenase activity is measured with cell suspensions: it is necessary to distinguish $\mathrm{N}_{2}$-fixing cells from non- $\mathrm{N}_{2}$-fixing cells in a culture.

In many unicellular diazotrophic cyanobacteria, including Gloeothece sp. 68DGA, used in this study, nitrogenase undergoes a daily cycle of synthesis and degradation, disappearing during the light phase under LD (Chow \& Tabita, 1994; Colón-López et al., 1997; Taniuchi \& Ohki, 2007). If $\mathrm{N}_{2}$-fixation and photosynthesis are separated diurnally within individual cells under CL, a considerable number of cells in the culture would not have nitrogenase. We have established an immunocytochemical method to detect nitrogenase in individual cells of cyanobacteria (Taniuchi et al., 2008). In this study, immunodetection of nitrogenase in individual cells of Gloeothece sp. 68DGA was carried out during the acclimation processes between LD and CL. As acclimation took several generations (cf. Taniuchi \& Ohki, 2007), Gloeothece sp. 68DGA was grown in a continuous-culture device to maintain constant cell density. We measured abundance of the nitrogenasecontaining cells and changes in nitrogenase activity, photosynthesis and respiration in cultures that were acclimated to either LD or CL, and during the transition phase between LD and CL.

\section{METHODS}

Strain and culture conditions. Gloeothece sp. 68DGA was the same strain as used in our previous studies (Ohki et al., 2008; Taniuchi \& Ohki, 2007). Culture conditions were also the same as those described previously (Taniuchi \& Ohki, 2007). Seed cultures were maintained under $12 \mathrm{~h}$ light/12 h dark cycles (LD) or under continuous light (CL) with air-bubbling.

A chemostat-type continuous-culture device equipped with a cylindrical culture vessel $(500 \mathrm{ml})$ was used for all experiments (Ikeya et al., 1997). The cells from the seed culture were inoculated into the culture vessel of the continuous-culture device filled with fresh medium. After the cell density in the vessel reached 2.0$2.5 \times 10^{6}$ cells $\mathrm{ml}^{-1}$, fresh medium was introduced at a dilution rate of $0.016 \mathrm{~h}^{-1}$ (for LD) or $0.011 \mathrm{~h}^{-1}$ (for CL) to maintain constant cell density. Growth rates were determined by counting the cell number using a bacteria-counting chamber under a light microscope, and the means \pm SD of five separate counts are presented.
Nitrogenase activity. Nitrogenase activity was measured using the acetylene reduction method as described previously (Ohki \& Fujita, 1988).

Photosynthesis and respiration. $\mathrm{O}_{2}$-evolution and respiration were measured with a Clark-type $\mathrm{O}_{2}$ electrode (Hansatech Oxygraph; Hansatech Instruments) as described previously (Taniuchi \& Ohki, 2007).

Nitrogenase detection. Conditions for SDS-PAGE and Western blot analysis were the same as those described previously (Taniuchi \& Ohki, 2007). For immunocytochemical detection of nitrogenase, cells were fixed in paraformaldehyde and preserved in methanol at $-30{ }^{\circ} \mathrm{C}$ until use. The fixed cells were treated with DMSO (for permeabilization) and non-immune rabbit serum (for blocking), and then incubated with polyclonal antibody generated against the recombinant Fe-protein of nitrogenase (NifH) from Trichodesmium sp. NIBB1067 (Ohki, 2008). The immunoreaction was visualized with horseradish-peroxidase-conjugated secondary antibody and chromogenic substrate, $3,3^{\prime}$-diaminobenzidine tetrachloride $(\mathrm{DAB})$ in the presence of $\mathrm{H}_{2} \mathrm{O}_{2}$. Detailed conditions for the immunocytochemical analysis are available in Taniuchi et al. (2008). The percentage of the immunostained cells in the culture was determined by triplicate counting of 200 cells under the light microscope.

Transcriptional analysis by RT-PCR. Total RNA was extracted from equal numbers of cells $\left(\sim 3.0 \times 10^{8}\right.$ cells $)$ using the Rneasy Plant Mini kit (Qiagen) and preserved at $-80{ }^{\circ} \mathrm{C}$. The RNA preparations were treated with RNase-free DNase I [DNase (RT Grade) for Heat Stop, Wako] to eliminate possible genomic DNA contamination. The first-strand cDNAs were synthesized from total RNA using the SuperScript First-Strand Synthesis System for RT-PCR (Invitrogen). PCR was carried out with the primer pair HFF $\left(5^{\prime}\right.$ ACACCAAAGCACAAACCACCA-3')/HRR (5'-GCTTTTCCTTCACGGATAGGCAT-3') to amplify the 322 bp of nifH (Ohki et al., 2008). The $449 \mathrm{bp}$ of $r p B$ fragment was used as an internal control for the RT-PCR analysis with the primer pair $r n p B-\mathrm{F}\left(5^{\prime}\right.$-TGAGGAAAGTCCGGGCT- $3^{\prime}$ )/rnpB-R (5'-TAAGCCGGGTTCTGTTC-3') (Vioque, 1997). The PCR conditions were as follows: 24 or 30 cycles at $94{ }^{\circ} \mathrm{C}$ for $30 \mathrm{~s}, 55{ }^{\circ} \mathrm{C}$ for $30 \mathrm{~s}$, and $72{ }^{\circ} \mathrm{C}$ for $30 \mathrm{~s}$. Negative control reactions were carried out without reverse transcriptase.

\section{RESULTS}

\section{Transition from $L D$ to $C L$}

Changes of abundance and activity (measured as acetylene reduction) of nitrogenase, the capacity for net $\mathrm{O}_{2}$ evolution (apparent photosynthetic activity) and respiration of Gloeothece sp. 68DGA during the transition from $\mathrm{LD}$ to $\mathrm{CL}$ are summarized in Fig. 1. In agreement with our previous results (Taniuchi \& Ohki, 2007), nitrogenase activity was restricted to the dark phase and its peak appeared around the middle of the dark phase in LD (Fig. la, 0-24 h). The mean of the maximum nitrogenase activity $\left[27.6 \pm 2.1 \times 10^{-16}\left(\mathrm{~mol} \mathrm{C}_{2} \mathrm{H}_{4}\right) \mathrm{h}^{-1}\right.$ cell $\left.^{-1}\right]$ under LD was the same as that of the cells in the exponential growth phase of a batch culture (Taniuchi \& Ohki, 2007). The capacities for net $\mathrm{O}_{2}$-evolution and respiration were inversely correlated: $\mathrm{O}_{2}$-evolution peaked in the middle of the light phase, while respiration peaked during the middle of the dark phase (Fig. 1b, 0-24 h). Immunoreactive bands corresponding to the Fe-protein (apparent molecular 


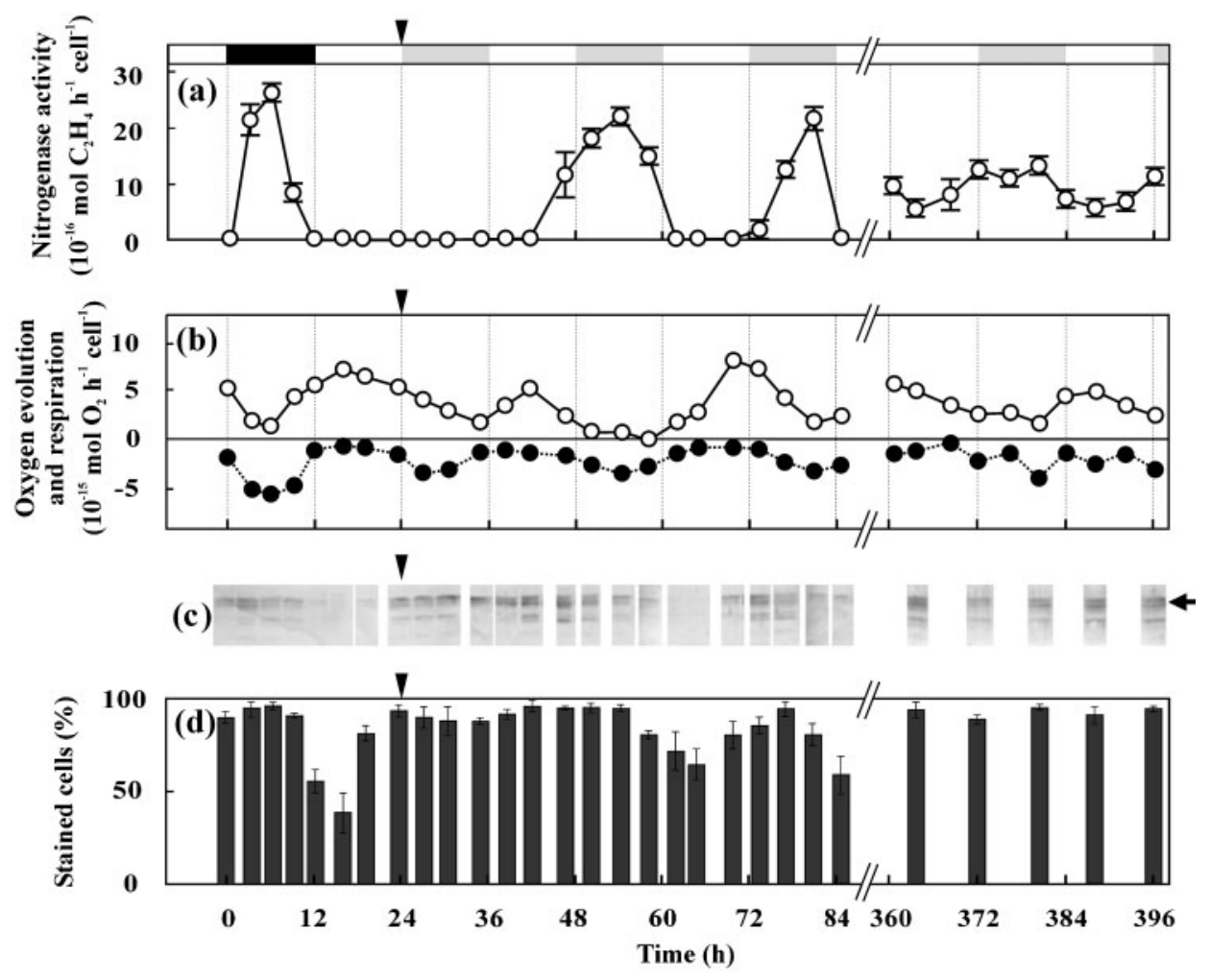

Fig. 1. Changes in nitrogenase activity (acetylene reduction activity), net $\mathrm{O}_{2}$-evolution, respiration and the abundance of nitrogenase (the Fe-protein) and the percentage of immunostained cells following transfer of Gloeothece sp. 68DGA cells from LD to CL. Cells were grown in a continuous-culture device in a medium without combined nitrogen to maintain cell density at around $2 \times 10^{6}$ cells ml $^{-1}$. The cells were cultured for several generations under LD (LD-acclimated cells) and then transferred to $\mathrm{CL}$ (indicated by the arrowheads at $24 \mathrm{~h}$ ). The black and grey shading in the upper bar indicate the dark phase of LD and the subjective dark phase (the period corresponding to the dark phase in LD) of CL, respectively. (a) Nitrogenase activity measured by acetylene reduction. The mean and standard deviation of the results from triplicate measurements are shown for each time point. (b) Net $\mathrm{O}_{2}$-evolution (open circles) and respiration (closed circles) measured with an $\mathrm{O}_{2}$ electrode. Means of the results from duplicate measurements are presented. (c) Western blot analysis of the Fe-protein. Soluble fractions extracted from about $2.5 \times 10^{7}$ cells were subjected to SDS-PAGE. The Fe-protein was detected using an anti-Fe-protein antibody. The immunostained bands of 41 and $37 \mathrm{kDa}$ that correspond to the Fe-protein are indicated by an arrow. (d) Proportion of nitrogenase-containing cells in the culture, determined by immunostaining of the cells as described in Methods. The mean \pm SD of the results from triplicate counts of 200 cells is shown for each time point. See Fig. S1 for microscopic images of the immunostained cells.

masses of 41 and $37 \mathrm{kDa}$ on SDS-PAGE, Figs $1 \mathrm{c}$ and $2 \mathrm{c}$, indicated by an arrow) were detected $2 \mathrm{~h}$ prior to the appearance of nitrogenase activity, and disappeared at the end of the dark phase (Fig. 1c, $0-24 \mathrm{~h}$ ). In addition, faint immunoreactive protein bands, with an apparent molecular mass of $\sim 27 \mathrm{kDa}$, were often observed when large amounts of the 41 and $37 \mathrm{kDa}$ proteins were present. About $85 \%$ of the cells were immunostained at the beginning of the dark phase of LD (Fig. 1d, $0 \mathrm{~h}$ ). The proportion of immunostained cells increased to about $97 \%$ after entering the dark phase and then rapidly decreased to about $60 \%$ at the end of the dark phase. It continued to decline in the light phase to reach a minimum near the middle of the light phase. Although the staining was faint (Fig. 1d, 12-24 h, and Supplementary Fig. S1, available with the online version of this paper), about $30 \%$ of the cells remained immunostained at this stage. The number of immunostained cells increased in the latter half of the light phase to reach about $80 \%$ at the end of the light phase. Hereafter, we refer to the cells that were cultured under $\mathrm{LD}$ as 'LD-acclimated cells'.

When LD-acclimated cells were transferred to CL (Fig. 1, from $24 \mathrm{~h}$ ), nitrogenase activity could not be detected during the first subjective dark phase (the period corresponding to the dark phase of LD, Fig. 1, 24-36 h). However, nitrogenase activity reappeared before starting the second subjective dark phase (Fig. 1a, $46 \mathrm{~h}$ ) as we have observed previously using batch culture (Taniuchi \& Ohki, 2007). Nitrogenase activity did increase towards the end of the first subjective light phase 
(the period corresponds to the light phase of LD, Fig. 1, $46 \mathrm{~h}$ ), and peaked near the middle of the second subjective dark phase (Fig. 1a, $54 \mathrm{~h}$ ), then decreased rapidly to zero $2 \mathrm{~h}$ after starting the second subjective light phase (Fig. 1a, $62 \mathrm{~h}$ ). Net $\mathrm{O}_{2}$-evolution declined during the first subjective dark phase but was always greater than zero (Fig. 1b, 24-36 h). $\mathrm{O}_{2}$-evolution substantially increased during the first half of the first subjective light phase (Fig. 1b, from $36 \mathrm{~h}$ ), and then decreased to zero during the second subjective dark phase (Fig. 1b, 48-60 h). The diurnal oscillation in respiration was maintained after transfer to CL (Fig. 1b, after $24 \mathrm{~h}$ ). The Feprotein was present during the first to second subjective dark phase even though its activity was not detected (Fig. 1a vs Fig. 1c, 24-42 h). The Fe-protein disappeared before the culture entered the third subjective light phase (Fig. 1c, 60-72 h). The proportion of immunostained cells remained high ( $>87 \%$ ) between the beginning of the first subjective dark phase and the middle of the second subjective dark phase (Fig. 1d, 24-54 h) and then decreased to about $60 \%$ near the middle of the second subjective light phase (Fig. 1d, $66 \mathrm{~h}$ ). The number of the immunostained cells oscillated diurnally for several generations after the second subjective light phase (Fig. 1d, from $72 \mathrm{~h}$ ). After prolonged incubation under CL, nitrogenase activity did not decrease to zero (Fig. 1a, from $360 \mathrm{~h}$ ), but it still oscillated between 5 and $15 \times 10^{-16}$ (mol $\left.\mathrm{C}_{2} \mathrm{H}_{4}\right) \mathrm{h}^{-1}$ cell ${ }^{-1}$, with the peak being observed during the subjective dark phase.

\section{Acclimation to $\mathrm{CL}$}

When the cells were cultured under CL for a prolonged period (more than nine generations, 23 days), the diurnal oscillation of nitrogenase activity, net $\mathrm{O}_{2}$-evolution, respiration and the abundance of the Fe-protein were no longer observed (Fig. 2, 1296-1464 h). Instead, nitrogenase activity, net $\mathrm{O}_{2}$-evolution and respiration remained constant at around $10.0 \pm 0.61 \times 10^{-16}\left(\mathrm{~mol} \mathrm{C}_{2} \mathrm{H}_{4}\right) \mathrm{h}^{-1}$ cell $^{-1}, \quad 6.9 \pm 0.28 \times 10^{-15}\left(\mathrm{~mol} \mathrm{O}_{2}\right) \mathrm{h}^{-1}$ cell $^{-1}$ and $-5.8 \pm 0.22 \times 10^{-15}\left(\mathrm{~mol} \mathrm{O}_{2}\right) \mathrm{h}^{-1}$ cell $^{-1}$, respectively (mean between 1296 and $1322 \mathrm{~h}$ ). Also, the level of the Fe-protein was constant (Fig. 2c). The majority of cells $(93.8 \pm 5.4 \%)$ were positively immunostained between 1296 and $1322 \mathrm{~h}$ (see also Supplementary Fig. S2). Hereafter, we refer to the cells that were fully acclimated to $\mathrm{CL}$ as 'CL-acclimated cells'.

\section{Transition from CL to LD}

The diurnal rhythm of nitrogenase activity resumed very rapidly after transfer of CL-acclimated cells to LD (Fig. 2a, from 1464-1476 h). Nitrogenase activity initially decreased during the first dark phase (Fig. 2a, 1476 h). However, the nocturnal increase in nitrogenase activity was restored during the second dark phase (Fig. 2a, from $1488 \mathrm{~h}$ ). Maximum nitrogenase activity during the second dark phase $\left[28.4 \pm 1.9 \times 10^{-16}\left(\mathrm{~mol} \mathrm{C}_{2} \mathrm{H}_{4}\right) \mathrm{h}^{-1}\right.$ cell $\left.^{-1}\right]$ was comparable to that of $\mathrm{LD}$-acclimated cells.

\section{Transcriptional analysis of nifH in the cells grown under $\mathbf{L D}$ and $C L$}

LD-acclimated cells showed diurnal oscillation of expression of nifH, the gene encoding the Fe-protein of nitrogenase (Fig. 3a). The transcript level increased during
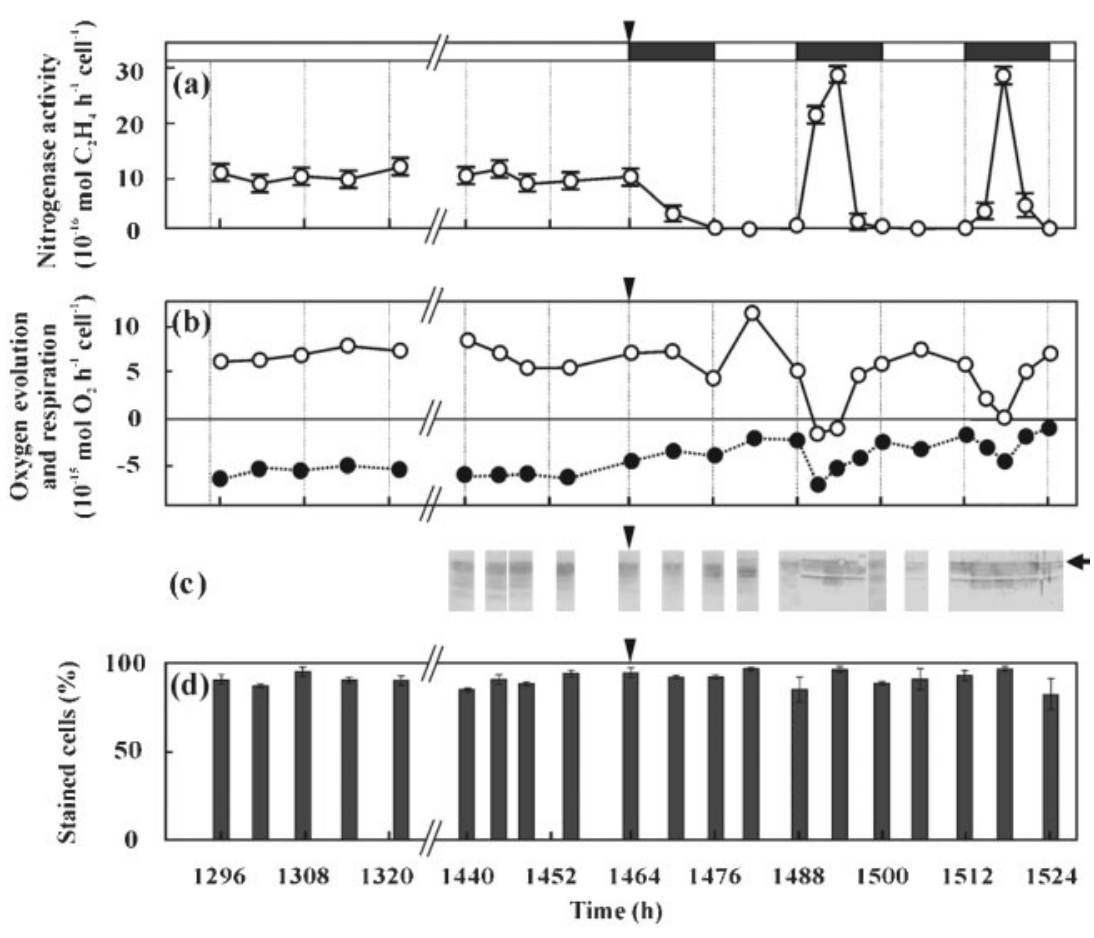

Fig. 2. Nitrogenase activity (acetylene reduction activity), net $\mathrm{O}_{2}$-evolution, respiration, the abundance of nitrogenase (the Fe-protein) and proportion of immunostained cells in CLacclimated cells and the changes thereto after transfer of the culture to LD. The time of transfer is indicated by the arrowheads (at $1464 \mathrm{~h}$ ). Experimental conditions were the same as those in Fig. 1. See Fig. S2 for microscopic images of the immunostained cells. 

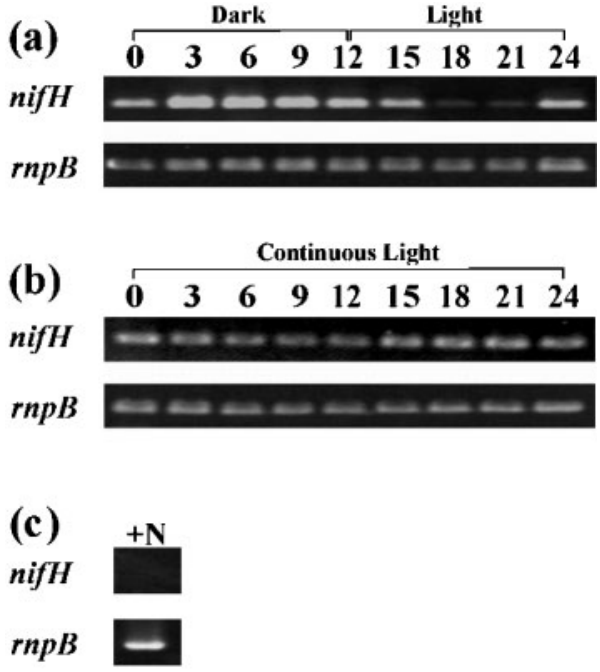

Fig. 3. RT-PCR analysis of the nifH gene transcript. The cells were collected at $3 \mathrm{~h}$ intervals from a culture grown under LD (a) or $\mathrm{CL}$ (b). Cells grown with combined nitrogen $\left(\mathrm{NaNO}_{3}\right)$ were used as a negative control (c). Total RNA extracted from $\sim 3 \times 10^{8}$ cells was used as a template.

the first half of the dark phase (Fig. 3a, 3 and $6 \mathrm{~h}$ ) and decreased gradually thereafter. The nifH transcript was almost undetectable in the middle of the light phase (Fig. 3a, 18 and $21 \mathrm{~h}$ ), and then appeared at the end of the light phase (Fig. 3a, 24 h). In contrast, CL-acclimated cells expressed nifH constitutively, although the expression level was slightly lower than the maximum level in LDacclimated cells (Fig. $3 \mathrm{a}, 3$ and $6 \mathrm{~h}$ vs Fig. 3b). The expression level of $\operatorname{rnp} B$ used as an internal control was almost the same in LD- and CL-acclimated cells. The nifH transcript could not be detected when total RNA extracted from the cells grown with combined nitrogen $\left(\mathrm{NaNO}_{3}\right)$ was used as a template for RT-PCR analysis (Fig. 3c).

\section{DISCUSSION}

When cells of Gloeothece sp. 68DGA were fully acclimated to $\mathrm{CL}$, they fixed $\mathrm{N}_{2}$ (reduced acetylene) constantly at a rate corresponding to one-third of the maximum rate of LD-acclimated cells (Fig. 1a, 0-12 h vs Fig. 2a, 1296$1322 \mathrm{~h}$ ). This level of $\mathrm{N}_{2}$-fixation activity was similar to that calculated by integrating and averaging the oscillating $\mathrm{N}_{2}$-fixation activity in LD-acclimated cells (37\% of the maximum), suggesting the possibility that individual CLacclimated cells expressed $\mathrm{N}_{2}$-fixation activity diurnally in a non-synchronous manner. Whole-cell immunodetection of nitrogenase, however, enabled us to exclude this possibility. As the proportion of nitrogenase-containing Gloeothece sp. 68DGA cells in LD-acclimated cultures oscillates between 97 and $30 \%$, the proportion of immunostained cells in a CL culture would be at most $65 \%$, if the culture consisted of non-synchronously oscillating cells. However, the proportion of immunostained cells in CL-acclimated cultures was far greater ( $94 \%$ on average, Fig. 2 d), indicating that virtually all the cells express nitrogenase and maintain enzyme activity constitutively in CL-acclimated culture. As the anti-Feprotein antibody used in this study reacted with proteins smaller than $35 \mathrm{kDa}$ that were probably the degradation products of the Fe-protein (Dougherty et al., 1996), as well as with the Fe-protein (Figs 1c, 2c), the proportion of the Fe-protein-containing cells would be overestimated. However, the calculations mentioned above are basically not changed because the overestimation of the Fe-proteincontaining cells may occur to a similar extent in CLacclimated culture and in LD-acclimated culture; the amount of the Fe-protein (41 and $37 \mathrm{kDa}$, indicated by an arrow in Fig. 1c and Fig. 2c) in CL-acclimated culture was the same as that during the dark phase of LDacclimated culture, and the immunostained bands smaller than $35 \mathrm{kDa}$ were present in both CL- and LD-acclimated cultures (Fig. 1c, $4-8 \mathrm{~h}$ vs Fig. 2c, 1440-1464 h). We thus conclude that nitrogenase synthesis and probably $\mathrm{N}_{2}$ fixation proceed without diurnal oscillation in the CLacclimated cells of Gloeothece sp. 68DGA. Direct detection of $\mathrm{N}_{2}$ uptake in individual cells (e.g. with a high-resolution nanometre-scale secondary-ion mass spectrometer, cf. Popa et al., 2007) is necessary to confirm the constitutive $\mathrm{N}_{2}$-fixation in CL-acclimated cultures. As the level of nitrogenase activity in CL-acclimated cells was low, it seems that the accumulation of intracellular fixed $\mathrm{N}$ (or the ratio of $\mathrm{N}$ to $\mathrm{C}$ in the cells) was insufficient to downregulate nitrogenase activity (cf. Taniuchi \& Ohki, 2007), forcing the cells to fix $\mathrm{N}_{2}$.

When LD-acclimated cells were transferred to CL, nitrogenase activity was not detected during the first subjective dark phase, although the nitrogenase was present (Fig. 1a). We previously showed that nitrogenase activity in the first subjective dark phase was restored when photosynthetic $\mathrm{O}_{2}$-evolution was inhibited by addition of 3-(3,4-dichlorophenyl)-1,1-dimethylurea or by reducing the light intensity (Taniuchi \& Ohki, 2007). Therefore, the inhibition of nitrogenase activity observed during the first subjective dark phase is to be ascribed to the inhibitory effect of $\mathrm{O}_{2}$. After full acclimation of the cells to CL, nitrogenase activity remained constant (Fig. 2a). As the net $\mathrm{O}_{2}$-evolution was higher in this phase than that during the first subjective dark phase (Fig. 1b, 24-36 h, vs Fig. 2b, open circles), the CL-acclimated cells seemed to have developed $\mathrm{O}_{2}$-tolerance. However, the $\mathrm{pO}_{2}$ that resulted in $50 \%$ inhibition of nitrogenase activity was the same $(\sim 0.3$ $\mathrm{pO}_{2}$ ) in both LD- and CL-acclimated cells (data not shown).

The high rate of respiration $\left(\mathrm{O}_{2}\right.$-uptake $)$ observed in CLacclimated cells (Fig. 1b vs Fig. 2b, closed circles) may be a mechanism(s) to reduce intracellular $\mathrm{pO}_{2}$. Respiratory protection of nitrogenase has been proposed in unicellular diazotrophic cyanobacteria (Maryan et al., 1986; Shieh \& Chang, 1992). Recently, Weng \& Shieh (2004) 
demonstrated a KCN-resistant and salicylhydroxamic acid (SHAM; inhibitor for plant mitochondria-type alternative oxidase)-sensitive $\mathrm{O}_{2}$ photoreduction pathway in Synechococcus sp. RF1. The electrons generated by photosytem II may be transferred from cytochrome $b_{6} f$ complex to $\mathrm{O}_{2}$ through ferredoxin. Nitrogenase activity of Synechococcus sp. RF1 decreased when this pathway was blocked by SHAM. Contributions of the Mehler reaction have been proposed for reducing the intracellular $\mathrm{pO}_{2}$ in Trichodesmium thiebautii, a non-heterocystous cyanobacterium that fixes $\mathrm{N}_{2}$ preferentially during the daytime (Kana, 1993). During the Mehler reaction, the electrons produced by photosynthesis are transferred to $\mathrm{O}_{2}$ to form superoxide. A single-step reduction of superoxide to $\mathrm{H}_{2} \mathrm{O}$ by A-type flavoproteins was demonstrated in Synechocystis sp. PCC6803 (Helman et al., 2003). Homologous genes encoding A-type flavoproteins were found in several cyanobacteria including Trichodesmium spp. In $\mathrm{N}_{2}$-fixing Trichodesmium colonies, about $75 \%$ of the $\mathrm{O}_{2}$ produced by photosynthesis was consumed by light-dependent $\mathrm{O}_{2}$ reduction, most likely via the Mehler reaction (Milligan et al., 2007). Similar mechanism(s) may be employed in Gloeothece sp. 68DGA.

The diurnal oscillation of nitrogenase activity was rapidly recovered after CL-acclimated cells were transferred to LD (Fig. 2, after 1488 h). An endogenous rhythm that regulates the onset of the diurnal oscillation in $\mathrm{N}_{2}$-fixation (cf. Taniuchi \& Ohki, 2007) appears to be reset by the insertion of a single dark phase (Fig. 2, 1464-1476 h). The downregulation of nitrogenase activity during the latter half of the second dark phase (Fig. 2, 1494-1500 h, cf. Taniuchi \& Ohki, 2007) seems to indicate that the level of fixed $\mathrm{N}_{2}$ increased to a high enough level during the first half of the second dark phase.

In conclusion, diurnal oscillation of nitrogenase synthesis and probably of $\mathrm{N}_{2}$-fixation and photosynthesis is not necessary for the diazotrophic growth of Gloeothece sp. 68DGA. Our results suggest that nitrogenase synthesis proceeds without diurnal oscillation in CL-acclimated cultures. Development of $\mathrm{O}_{2}$-uptake mechanism(s) to maintain low intracellular $\mathrm{pO}_{2}$ under $\mathrm{CL}$ has been suggested. The rapid recovery of diurnal oscillation observed upon transfer from CL to LD suggests that $\mathrm{N}_{2}-$ fixation in Gloeothece sp. 68DGA is primarily regulated by the endogenous rhythm, but is modulated in response to intracellular and environmental factors, e.g. the amount of fixed $\mathrm{N}_{2}$ and the changes in $\mathrm{pO}_{2}$.

\section{ACKNOWLEDGEMENTS}

This work was supported in part by the Sasakawa Scientific Research Grant from The Japan Science Society to Y.T. and by Grant-in-Aid for Scientific Research (C) 20580208 to K. O. We wish to express our thanks to Dr M. Kamiya of the Department of Marine Bioscience, Fukui Prefectural University, and Dr A. Murakami of the Kobe University Research Center for Inland Seas for their intensive discussion.

\section{REFERENCES}

Bergman, B., Gallon, J. R., Rai, A. N. \& Stal, L. J. (1997). $\mathrm{N}_{2}$ fixation by non-heterocystous cyanobacteria. FEMS Microbiol Rev 19, 139-185.

Chow, T. J. \& Tabita, F. R. (1994). Reciprocal light-dark transcriptional control of nif and $r b c$ expression and light-dependent posttranslational control of nitrogenase activity in Synechococcus sp. strain RF1. J Bacteriol 176, 6281-6285.

Colón-López, M. S., Sherman, D. M. \& Sherman, L. A. (1997). Transcriptional and translational regulation of nitrogenase in lightdark- and continuous-light-grown cultures of the unicellular cyanobacterium Cyanothece sp. strain ATCC51142. J Bacteriol 179, 4319-4327.

Dougherty, L. J., Brown, E. G. \& Gallon, J. R. (1996). Nitrogenasespecific proteolytic activity in the unicellular cyanobacterium Gloeothece. Biochem Soc Trans 24, 401S.

Fay, P. (1992). Oxygen relations of nitrogen fixation in cyanobacteria. Microbiol Rev 56, 340-373.

Gallon, J. R. (1992). Reconciling the incompatible: $\mathrm{N}_{2}$ fixation and $\mathrm{O}_{2}$. New Phytol 122, 571-609.

Gallon, J. R. \& Chaplin, A. E. (1988). Nitrogen fixation. In The Biochemistry of Algae and Cyanobacteria, pp. 147-173. Edited by L. J. Rogers \& J. R. Gallon. Oxford: Oxford University Press.

Grobbelaar, N., Huang, T. C., Lin, H. Y. \& Chow, T. J. (1986). Dinitrogen-fixing endogenous rhythm in Synechococcus RF-1. FEMS Microbiol Lett 37, 173-177.

Helman, Y., Tchernov, D., Reinhold, L., Shibata, M., Ogawa, T., Schwarz, R., Ohad, I. \& Kaplan, A. (2003). Genes encoding A-type flavoproteins are essential for photoreduction of $\mathrm{O}_{2}$ in cyanobacteria. Curr Biol 13, 230-235.

Huang, T.-C. \& Chow, T.-J. (1986). New type of $\mathrm{N}_{2}$-fixing unicellular cyanobacterium (blue-green alga). FEMS Microbiol Lett 36, 109-110.

Ikeya, T., Ohki, K., Takahashi, M. \& Fujita, Y. (1997). Study on phosphate uptake of the marine cyanophyte Synechococcus sp. NIBB 1071 in relation to oligotrophic environments in the open ocean. Mar Biol 129, 195-202.

Kana, T. M. (1993). Rapid oxygen cycling in Trichodesmium thiebautii. Limnol Oceanogr 38, 18-24.

Maryan, P. S., Eady, R. R., Chaplin, A. E. \& Gallon, J. R. (1986). Nitrogen fixation by Gloeothece sp. PCC 6909: respiration and not photosynthesis supports nitrogenase activity in the light. J Gen Microbiol 132, 789-796.

Milligan, A. J., Berman-Frank, I., Gerchman, Y., Dismukes, G. C. \& Falkowski, P. G. (2007). Light-dependent oxygen consumption in nitrogen-fixing cyanobacteria plays a key role in nitrogenase protection. J Phycol 43, 845-852.

Mitsui, A., Kumazawa, S., Takahasi, A., Ikemoto, H., Cao, S. \& Arai, T. (1986). Strategy by which nitrogen-fixing unicellular cyanobacteria grow photoautotrophically. Nature 323, 720-722.

Ohki, K. (2008). Intercellular localization of nitrogenase in a nonheterocystous cyanobacterium (Cyanophyte), Trichodesmium sp. NIBB1067. J Oceanogr 64, 211-216.

Ohki, K. \& Fujita, Y. (1988). Aerobic nitrogenase activity measured as acetylene reduction in the marine non-heterocystous cyanobacterium Trichodesmium spp. grown under artificial conditions. Mar Biol 98, 111-114.

Ohki, K., Kamiya, M., Honda, D., Kumazawa, S. \& Ho, K. K. (2008). Morphological and phylogenetic studies on unicellular diazotrophic cyanobacteria (Cyanophytes) isolated from the coastal waters around Singapore. J Phycol 44, 142-151. 
Ortega-Calvo, J. J. \& Stal, L. J. (1991). Diazotrophic growth of the unicellular cyanobacterium Gloeothece sp. PCC6909 in continuous culture. J Gen Microbiol 137, 1789-1797.

Popa, R., Weber, P. K., Pett-Ridge, J., Finzi, J. A., Fallon, S. J., Hutcheon, I. D., Nealson, K. H. \& Capone, D. G. (2007). Carbon and nitrogen fixation and metabolite exchange in and between individual cells of Anabaena oscillarioides. ISME J 1, 354-360.

Postgate, J. (1998). Nitrogen Fixation. Cambridge: Cambridge University Press.

Reddy, K. J., Haskell, J. B., Sherman, D. M. \& Sherman, L. A. (1993).

Unicellular, aerobic nitrogen-fixing cyanobacteria of the genus Cyanothece. J Bacteriol 175, 1284-1292.

Shieh, Y. J. \& Chang, S. T. (1992). Circadian rhythm of photosynthesis in Synechococcus RF-1. In 18th Annual Meeting of the Botanical Society of the Republic of China, Taiwan, p. 25.

Taniuchi, Y. \& Ohki, K. (2007). Relation between nitrogenase synthesis and activity in a marine unicellular diazotrophic strain, Gloeothece sp.
68DGA (Cyanophyte), grown under different light/dark regimens. Phycol Res 55, 249-256.

Taniuchi, Y., Murakami, A. \& Ohki, K. (2008). Whole cell immunocytochemical detection of nitrogenase in cyanobacteria: improved protocol for highly fluorescent cells. Aquat Microb Ecol (in press).

Vioque, A. (1997). The RNase P RNA from cyanobacteria: short tandemly repeated repetitive (STRR) sequences are present within the RNase P RNA gene in heterocyst-forming cyanobacteria. Nucleic Acids Res 25, 3471-3477.

Weng, J. H. \& Shieh, Y. J. (2004). Salicylhydroxamic acid (SHAM) inhibits $\mathrm{O}_{2}$ photoreduction which protects nitrogenase activity in the cyanobacterium Synechococcus sp. RF-1. Photosynth Res 82, 151-164. Wolk, C. P. (1999). Heterocyst formation in Anabaena. In Prokaryotic Development, pp. 83-104. Edited by Y. V. Brun \& L. J. Shimets. Washington, DC: American Society for Microbiology.

Edited by: K. Forchhammer 